\title{
Correction to: Understanding the carbonation of concrete with supplementary cementitious materials: a critical review by RILEM TC 281-CCC
}

\author{
Stefanie von Greve-Dierfeld $(\mathbb{D} \cdot$ Barbara Lothenbach $(\mathbb{D} \cdot$ Anya Vollpracht $\mathbb{D} \cdot$

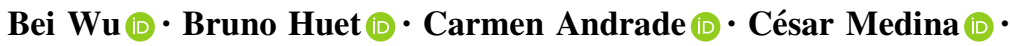 \\ Charlotte Thiel $(\mathbb{D} \cdot$ Elke Gruyaert $(\mathbb{D} \cdot$ - Hanne Vanoutrive $(\mathbb{D} \cdot$ Isabel F. Saéz del Bosque $(\mathbb{D})$ \\ Ivan Ignjatovic $\mathbb{D} \cdot$ Jan Elsen $(\mathbb{D} \cdot$ John L. Provis $\mathbb{D} \cdot$ Karen Scrivener $\mathbb{D} \cdot$ \\ Karl-Christian Thienel $(\mathbb{D} \cdot$ Kosmas Sideris $(\mathbb{D} \cdot$ Maciej Zajac $\cdot$ Natalia Alderete $(\mathbb{D} \cdot$ \\ Özlem Cizer (D) Philip Van den Heede 1 - Robert Douglas Hooton ( \\ Siham Kamali-Bernard (1) Susan A. Bernal 1 - Zengfeng Zhao $(\mathbb{D})$ \\ Zhenguo Shi $\mathbb{( D )} \cdot$ Nele De Belie $\mathbb{B}$
}

Published online: 31 March 2021

(C) The Author(s) 2021

\section{Correction to:}

Materials and Structures (2020) 53:136

https://doi.org/10.1617/s11527-020-01558-w

The article "Understanding the carbonation of concrete with supplementary cementitious materials: a critical review by RILEM TC 281-CC”, written by

The original article can be found online at https:// doi.org/10.1617/s11527-020-01558-w.

S. von Greve-Dierfeld $(\bowtie)$

TFB Technology and Research for Concrete Structures,

Wildegg, Switzerland

e-mail: stefanie.vongreve@tfb.ch

B. Lothenbach · Z. Shi

Swiss Federal Laboratories for Materials Science and Technology (Empa), Laboratory for Concrete and

Construction Chemistry, Dübendorf, Switzerland

\section{A. Vollpracht}

Faculty of Civil Engineering, Institute of Building

Materials Research, RWTH Aachen University, Aachen, Germany

B. $\mathrm{Wu}$

Microlab, Faculty of Civil Engineering and Geosciences, Delft University of Technology, Delft, The Netherlands
Stefanie von Greve-Dierfeld, Barbara Lothenbach, Anya Vollpracht, Bei Wu, Bruno Huet, Carmen Andrade, César Medina, Charlotte Thiel, Elke Gruyaert, Hanne Vanoutrive, Isabel F. Saéz del Bosque, Ivan Ignjatovic, Jan Elsen, John L. Provis, Karen Scrivener, Karl-Christian Thienel, Kosmas Sideris, Maciej Zajac, Natalia Alderete, Özlem Cizer, Philip Van den Heede, Robert Douglas Hooton, Siham Kamali-Bernard, Susan A. Bernal, Zengfeng Zhao, Zhenguo Shi and Nele De Belie was originally published electronically on the publisher's internet

B. Huet

LafargeHolcim Innovation Center,

Saint-Quentin-Fallavier Cedex, France

C. Andrade

International Centre for Numerical Methods in

Engineering (CIMNE), Barcelona, Spain

C. Medina - I. F. S. del Bosque

Department of Construction, Institute for Sustainable

Regional Development (INTERRA), University of

Extremadura, Cáceres, Spain

C. Thiel

Center for Building Materials, Technical University of Munich, Munich, Germany 
portal on 22 October 2020 without open access. The copyright of the article changed in February 2021 to (C) The Author(s) 2021 and the article is forthwith distributed under the terms of the Creative Commons Attribution 4.0 International License (https:// creativecommons.org/licenses/by/4.0/), which permits use, duplication, adaptation, distribution and reproduction in any medium or format, as long as you give appropriate credit to the original author(s) and the source, provide a link to the Creative Commons license and indicate if changes were made.

E. Gruyaert · H. Vanoutrive

Department of Civil Engineering, Structural Mechanics and Building Materials, KU Leuven, Ghent, Belgium

\section{Ignjatovic}

Department of Materials and Structures, Faculty of Civil Engineering, Institute of Materials and Structures,

University of Belgrade, Belgrade, Serbia

J. Elsen

Department of Earth and Environmental Sciences, KU

Leuven, Louvain, Belgium

J. L. Provis

Department of Materials Science and Engineering, University of Sheffield, Sheffield S1 3JD, UK

\section{K. Scrivener}

Construction Materials Laboratory, École polytechnique fédérale de Lausanne, Lausanne, Switzerland

\section{K.-C. Thienel}

Department of Civil Engineering and Environmental Sciences, University of the Bundeswehr Munich, Neubiberg, Germany

K. Sideris

Department of Civil Engineering, Democritus University of Thrace, Xanthi, Greece
Open Access This article is distributed under the terms of the Creative Commons Attribution 4.0 International License (https://creativecommons.org/ licenses/by/4.0/), which permits unrestricted use, distribution, and reproduction in any medium, provided you give appropriate credit to the original author(s) and the source, provide a link to the Creative Commons license, and indicate if changes were made.

Publisher's Note Springer Nature remains neutral with regard to jurisdictional claims in published maps and institutional affiliations.

M. Zajac

Global R\&D, HeidelbergCement AG, Leimen, Germany

N. Alderete $\cdot$ P. Van den Heede $\cdot$ N. De Belie

Department of Structural Engineering and Building

Materials, Ghent University, Ghent, Belgium

Ö. Cizer

Departement of Civil Engineering, KU Leuven, Louvain, Belgium

R. D. Hooton

Department of Civil and Mineral Engineering, University of Toronto, Toronto, Canada

S. Kamali-Bernard

National Institute of Applied Sciences of Rennes, Rennes, France

S. A. Bernal

School of Civil Engineering, University of Leeds, Leeds, UK

\section{Z. Zhao}

Building Materials, Urban and Environment Research, University of Liège, Liège, Belgium 